\begin{tabular}{c} 
KONSTAN \\
JURNAL FISIKA DAN PENDIDIKAN FISIKA \\
Volume 6, Nomor 1, Juni 2021 \\
$\begin{array}{c}\text { E-ISSN : 2460-9129 dan P-ISSN : 2460-9110 } \\
\text { http://jurnalkonstan.ac.id/index.php/jurnal }\end{array}$ \\
\hline
\end{tabular}

\title{
Efektivitas Project Based Learning Terhadap Efikasi Diri dan Kemampuan Berpikir Kritis Peserta Didik
}

\author{
Tursina Ratu ${ }^{1, *)}$, Nursina Sari ${ }^{2}$, Wiji Aziz Hari Mukti ${ }^{3}$, Muhammad Erfan ${ }^{4}$ \\ ${ }^{1)}$ Universitas Samawa, Jl. Bypass Sering, Sumbawa Besar, Nusa Tenggara Barat, Indonesia \\ ${ }^{2}$ Universitas Mubammadiyah Mataram, Jl. KH. Abmad Dablan, Kota Mataram, Nusa Tenggara Barat, \\ Indonesia \\ ${ }^{3}$ Institut Agama Islam Negeri Bengkulu, Jl. Raden Patah, Kota Bengkulu, Bengkulu, Indonesia \\ ${ }^{4}$ Universitas Mataram, Jl. Majapabit No. 62, Kota Mataram, Nusa Tenggara Barat, Indonesia
}

*E-mail korespondensi: ratutursina@gmail.com

\begin{abstract}
Info Artikel: Abstrak
Dikirim:

8 April 2021

Revisi:

12 Mei 2021

Diterima:

17 Mei 2021

Model pembelajaran yang sesuai merupakan bagian penting dalam kegiatan proses belajar dalam mencapai tujuan pembelajaran yang direncanakan. Tujuan artikel penelitian ini adalah mengetahui pengaruh model pembelajaran Project Based Learning (PjBL) terhadap self-efficacy (efikasi diri) dan kemampuan berpikir kritis peserta didik selaku calon pendidik. Jenis penelitian ini adalah kuantitatif berpendekatan kuasi eksperimen dengan one group pretest-postest design dengan teknik purposive sampling. Instrumen yang digunakan berupa lembar penilaian berbasis Physics Self Efficacy Scale

Kata Kunci:

PjBL, Efikasi Diri, Berpikir Kritis, Fisika dengan teknik analisis deskriptif untuk mengukur efikasi diri dan soal tes bentuk essay dengan teknik analisis paired sample t-test dan N-Gain untuk mengukur peningkatan kemampuan berpikir kritis peserta didik. Hasil penelitian diperoleh bahwa efikasi diri peserta didik Aspek efikasi diri dalam menyelesaikan masalah fisika peserta didik sebesar $79 \%$, Aspek efikasi diri dalam mempelajari fisika peserta didik sebesar $81 \%$, Aspek efikasi diri dalam menerapkan pengetahuan fisika peserta didik sebesar 75\%, Aspek efikasi diri dalam mengingat pengetahuan fisika peserta didik sebesar $78 \%$, Aspek efikasi diri dalam melakukan percobaan fisika peserta didik sebesar $82 \%$. Sebaliknya, kemampuan berpikir kritis peserta didik menunjukkan bahwa t-hitung $>\mathrm{t}$ tabel yaitu $25.562>2.446$ maka $\mathrm{H}_{0}$ ditolak dan $\mathrm{H}_{a}$ diterima. $\mathrm{N}-\mathrm{G}$ ain diperoleh sebesar 0.68 artinya teradapat pengaruh dan mengalami peningkatan yang cukup signifikan. Dapat disimpulkan bahwa penggunaan model PjBL dalam pembelajaran fisika berpengaruh terhadap efikasi diri dan kemampuan berpikir kritis peserta didik sebagai calon pendidik.
\end{abstract}

(C) 2021 Universitas Islam Negeri Mataram

\section{PENDAHULUAN}

Pendidikan menjadi bagian terpenting dalam pembangunan sebuah bangsa. Pengembangan sumber daya manusia tidak luput dari peranan pendidikan. Tidaklah heran jika tujuan dari pendidikan satu diantaranya adalah mencerdaskan kehidupan bangsa. Artinya, masa depan bangsa menjadi tugas penting yang diemban oleh pendidikan dalam mempersiapkan generasi emas untuk dapat bersaing secara global. Kondisi ini menjadi isyarat bahwa peningkatan mutu pendidikan perlu diperhatikan lebih serius lagi sehingga generasi selanjutnya dapat bersaing secara unggul dalam era globalisasi saat ini. Mutu pendidikan tidak terlepas dari proses pembelajaran. Pembelajaran yang baik akan memberikan hasil belajar yang baik. 
Pembelajaran adalah rangkaian aktivitas yang memungkinkan terjadinya kegiatan belajar yang ditandai dengan adanya komunikasi dan interaksi antara pendidik dengan peserta didik, bahan ajar dan lingkungan. Hal ini bertujuan agar terdapat ketercapaian dalam kegiatan belajar yaitu peserta didik memiliki perubahan dalam hal kompetensi yang dimilikinya. Untuk dapat membuat proses pembelajaran yang baik, seorang pendidik harus memiliki pemahaman dan cara bagaimana memperkenalkan dan membuat peserta didik dapat mendalami bidang keilmuan yang ada. Selain itu, pendidik juga harus dapat membantu peserta didik mengembangkan kompetensi yang ada dalam diri mereka tidak hanya secara tertulis namun juga harus dapat menerapkannya dalam kehidupan seharihari. Fisika merupakan bidang ilmu yang memiliki konsep pembelajaran tidak lepas dari aktivitas hidup sehari-hari.

Pembelajaran fisika pada hakikatnya membantu seseorang untuk dapat mempelajari dan menganalisis alam sekitar serta mampu membangun model dan mengembangkan instrument dari gejala kelimuan yang diperoleh dari hasil pengamatan. Artinya, melalui pembelajaran fisika peserta didik diharapkan dapat memiliki kemampuan/keterampilan sebagai hasil belajar. Kemampuan/keterampilan tersebut tergambar dari aktivitas pembelajaran yang tengah berlangsung. Namun, hasil belajar fisika peserta didik sebagai calon pendidik secara umum masih belum optimal yang ditandai dengan rendahnya efikasi diri (self-efficacy). Efikasi diri yang rendah dapat dinilai dari kuantitas dan kualitas keterlibatan peserta didik dalam mengajukan pertanyaan, memberikan tanggapan/respon dan jawaban dari permasalahan/persoalan yang diberikan oleh pendidik saat di dalam kelas. Selain itu, motivasi dan rasa ingin tahu peserta didik juga masih belum memuaskan yang dapat dilihat dari ketekunan, ketangkasan dan pengetahuan kognitifnya dalam menyelesaikan soal-soal yang bersifat otentik dan tugas penelitian yang diberikan oleh pendidik baik secara individu maupun berkelompok.

Ciri-ciri efikasi diri pada diri seseorang dikatakan tinggi apabila seseorang tersebut percaya pada kemampuan yang dimiliki dan tetap mengerjakan tugas yang diberikan sekalipun tugas tersebut sulit [1]. Efikasi diri berhubungan dengan keyakinan seseorang bahwa dia dapat melakukan sesuatu yang memadai untuk menghadapi situasi tertentu [2]. Efikasi diri tidak hanya meyakini bahwa diri memiliki kemampuan, tetapi juga mendorong untuk berhasil dalam menghadapi permasalahan [3]. Efikasi diri juga menggambarkan harapan seseorang untuk sukses, dimana pencapaian sebelumnya juga menjadi acuan untuk memberikan informasi sejauh mana dia mampu atau sukses dalam memberikan kinerjanya [4]. Efikasi diri juga sebagai pembangun motivasi pada diri seseorang dalam mengasah kemampuan berpikir kritis [5]-[8]. Kemampuan berpikir kritis dan keterkaitannya dengan efikasi diri merupakan salah satu karakteristik guru yang penting untuk dikuasai dan mendapat perhatian luas dalam literatur terbaru tentang pendidikan guru [9]. Artinya, dengan efikasi diri yang tinggi memungkinkan peserta didik dapat mengubah sesuatu hal yang terjadi di sekitarnya. Secara tidak langsung, peserta didik juga dapat meningkatkan pengetahuan yang dimilikinya melalui kemampuan berpikir tingkat tinggi.

Berpikir kritis merupakan bagian dari kemampuan berpikir tingkat tinggi yang pada hakikatnya penting untuk dimiliki oleh peserta didik. Berpikir kritis merupakan pengenalan yang bersifat komprehensif agar dapat melakukan penalaran yang lebih baik [10]. Mengingat bahwa, kemampuan berpikir kritis menjadi syarat bagi peserta didik untuk dapat memecahkan permasalahan yang terjadi di masa yang akan datang selain dari kegiatan pembelajaran di kelas. Kemampuan berpikir kritis akan membuat seseorang dalam mengambil keputusan atau tindakan yang tepat terhadap permasalahannya [11]. Artinya, melalui kemampuan berpikir kritisnya peserta didik dapat menjadi lebih rasional dan reflektif dalam memecahkan permasalahan dengan mencari alternatif solusi terlebih dahulu sebelum membuat dan mengambil keputusan.

Peserta didik terdorong untuk dapat berpikir kritis dengan cara mengeksplorasi percobaan melalui beberapa serangkaian pertanyaan sehingga membantu mereka untuk dapat mengembangkan pemahaman konsep [12]. Melalui kegiatan eksplorasi tersebut, peserta didik secara tidak langsung memiliki pengalaman belajar secara mandiri dalam mengembangkan kemampuan berpikir kritisnya. Tentunya, pengalaman belajar yang baik dapat diperoleh jika menggunakan model pembelajaran yang tepat. Salah satu model pembelajaran yang dapat mengakomodasi peserta didik untuk dapat mengeksplor pengalaman belajar yang dimilikinya adalah Project Based Learning (PjBL). Model PjBL 
adalah suatu model pembelajaran yang menggunakan masalah sebagai langkah awal dalam mengumpulkan dan mengintegrasikan pengetahuan baru berdasarkan pengalaman dan kreativitas yang nyata [13]. Pengajuan masalah kepada peserta didik tentunya dengan memperhatikan sintaks/komponen dari model PjBL tersebut.

Komponen penting dalam model PjBL adalah mengorganisir dan memberikan aktivitas pada peserta didik. Kondisi ini mengisyaratkan bahwa, kegiatan project yang dilakukan oleh peserta didik tersebut disertai dengan adanya kegiatan penyelidikan guna memperdalam topik atau pertanyaan yang diberikan oleh pendidik sebelum melakukan proses pembelajaran [14]. Pertanyaan-pertanyaan yang diberikan tidak terlepas dari permasalahan suatu topik pelajaran yang akan dibahas. Dalam hal ini, peserta didik mengidentifikasi, mengumpulkan data, menyimpulkan dan mengkomunikasikan informasi yang diperoleh [15]. Komponen lanjutannya adalah menghasilkan suatu produk/hasil untuk menjawab pertanyaan/permasalahan yang telah diberikan sehingga jawaban tersebut menjadi titik penemuan pengetahuan/konsep [16]. Artinya, project berpusat pada pengembangan produk/unjuk kerja yang melibatkan adanya kegiatan-kegiatan dalam membantu perkembangan kemampuan berpikir kritis peserta didik. Kegiatan-kegiatan yang dimaksud berupa pencarian isu/masalah, perencanaan, penerapan dan pengevaluasian. Sebaliknya tugas pendidik dalam hal ini adalah hanya bertindak sebagai pendamping, fasilitator, dan memahami pola pikir peserta didik.

Berdasarkan hasil pemaparan di atas, dapat diasumsikan bahwa model PjBL dalam pembelajaran fisika mempunyai potensi yang cukup efektif dalam melatih efikasi diri dan proses berpikir kritis peserta didik. Pada tiap tahapan pembelajaran model PjBL, memungkinkan efikasi diri dan kemampuan berpikir ktitis peserta didik dapat dikembangkan dan ditingkatkan.

\section{METODE PENELITIAN}

Penelitian ini merupakan penelitian kuantitatif berpendekatan kuasi eksperimen yaitu penelitian eksperimen namu pemilihan subjek penelitian tidak dilakukan secara random. Sehingga desain yang digunakan dalam penelitian berupa one group pretest-postest design. Sampel ditentukan dengan menggunakan teknik purposive sampling dengan pertimbangan tertentu. Sampel yang digunakan adalah calon guru yang telah menempuh mata kuliah penelitian pendidikan dengan terfokus pada riset di lapangan (sekolah) pada semester ganjil 2020/2021. Instrumen yang digunakan berupa lembar penilaian angket berbasis Physics Self Efficacy Scale (PSES) untuk mengukur efikasi diri (self efficacy) dengan menggunakan teknik analisis deskriptif [17]. Angket pengukuran efikasi diri mengacu pada kisi-kisi skala efikasi diri dalam pembelajaran fisika yang merujuk hasil penelitian yang dilakukan oleh Caliş,kan, Selçuk \& Erol [18]. Sebaliknya soal tes bentuk essay yang dikembangkan oleh peneliti yang digunakan untuk mengukur kemampuan berpikir kritis peserta didik, hasilnya dianalisis dengan paired sample t- test dan N-Gain untuk mengetahui seberapa besar peningkatan dari pengaruh yang dihasilkan. Tinggi rendahnya hasil uji $\mathrm{N}$-gain dikategorikan dalam tiga kategori (tinggi, sedang, rendah) yang disajikan pada Tabel 1 [19]-[22].

Tabel 1. Kriteria Skor/Nilai Gain Ternormalisasi

\begin{tabular}{cc}
\hline Kriteria Peningkatan Nilai Gain & Nilai Gain Ternormalisasi \\
\hline Gain Tinggi & $\mathrm{g} \geq 0,7$ \\
Gain Sedang & $0,3 \leq \mathrm{g}<0,7$ \\
Gain Rendah & $\mathrm{g}<0,3$ \\
\hline
\end{tabular}

\section{HASIL DAN PEMBAHASAN}

Penelitian ini lebih memfokuskan pada penggunaan model project based learning (PjBL) terhadap efikasi diri dan kemampuan berpikir kritis peserta didik. Kisi-kisi angket efikasi diri disajikan pada Tabel 2. 
Tabel 2. Kisi-Kisi Angket Efikasi Diri

\begin{tabular}{|c|c|}
\hline Aspek yang diukur & Nomor Pernyataan \\
\hline $\begin{array}{l}\text { Efikasi diri dalam menyelesaikan masalah fisika (self efficacy towards } \\
\text { solving physics problem) }\end{array}$ & $\begin{array}{l}2,3,5,8,14,16,18,22 \\
29,25\end{array}$ \\
\hline Efikasi diri dalam mempelajari fisika (self efficacy towards learning physics) & $4,9,10,24,26$ \\
\hline $\begin{array}{l}\text { Efikasi diri dalam menerapkan pengetahuan fisika (self efficacy towards } \\
\text { application of physics knowledge) }\end{array}$ & $1,6,17,28$ \\
\hline $\begin{array}{l}\text { Efikasi diri dalam mengingat pengetahuan fisika (self efficacy towards } \\
\text { memorizing physics knowledge) }\end{array}$ & $12,13,15,19,20$ \\
\hline $\begin{array}{l}\text { Efikasi diri dalam melakukan percobaan fisika (self efficacy towards physics } \\
\text { laboratory) }\end{array}$ & $7,11,21,23,27,30$ \\
\hline
\end{tabular}

Aspek yang terdapat dalam kisi-kisi angket terangkum dalam 30 butir pernyataan yang diberikan saat pretest dan posttets dengan estimasi waktu yang diberikan sekitar 10 menit. Angket efikasi diri menggunakan skala likert dengan option yaitu Sangat Setuju, Setuju, Ragu-Ragu, Tidak Setuju dan Sangat Tidak Setuju. Di lain hal, untuk mengukur kemampuan berpikir kritis peserta didik menggunakan soal essay. Kisi-Kisi soal uraian yang betujuan untuk mengukur kemampuan berpikir kritis dapat dilihat pada Tabel 3.

Tabel 3. Kisi-Kisi Butir Soal Uraian Kemampuan Berpikir Kritis

\begin{tabular}{|c|c|c|}
\hline \multicolumn{2}{|c|}{ Aspek/Sub Aspek Kemampuan Berpikir Kritis } & Nomor Butir Soal \\
\hline \multirow{5}{*}{ Menganalisis (C4) } & \multirow{2}{*}{ Membedakan } & 1 \\
\hline & & 5 \\
\hline & \multirow{2}{*}{ Mengorganisasikan } & 7 \\
\hline & & 3 \\
\hline & Mengatribusikan & 8 \\
\hline \multirow{3}{*}{ Mengevaluasi (C5) } & Mengecek & 10 \\
\hline & Mengkritik & 6 \\
\hline & Memberi Tanggapan & 9 \\
\hline \multirow{2}{*}{ Mencipta (C6) } & Memunculkan Ide & 2 \\
\hline & Merancang & 4 \\
\hline
\end{tabular}

Butir-butir soal kemampuan berpikir kritis yang ada pada Tabel 2 tersebut dikembangkan dengan mengadopsi kata kerja operasional pada level kemampuan berpikir tingat tinggi [23]. Soal-soal essay tersebut berjumlah 10 butir yang diberikan pada saat pretest maupun posttest.

Berdasarkan kisi-kisi angket efikasi diri pada Tabel 1, maka data efikasi diri dapat dianalisis dengan menggunakan analisis deskriptif. Hasil analisis tersebut, dapat dilihat pada Gambar 1 persentase rata-rata efikasi diri yang tersaji di bawah ini.

Merujuk pada Gambar 1 yang menunjukkan bahwa efikasi diri peserta didik untuk masingmasing aspek mengalami peningkatan yang dapat dilihat pada perbedaan besarnya kisaran persentase pretest dan posttest. Aspek efikasi diri dalam menyelesaikan masalah fisika peserta didik pada saat pretest sebesar 58\% namun saat posttest menjadi 79\%, Aspek efikasi diri dalam mempelajari fisika peserta didik saat pretest sebesar 60\% namun saat posttest menjadi 81\%, Aspek efikasi diri dalam menerapkan pengetahuan fisika peserta didik saat pretest sebesar 59\% namun saat posttest menjadi 75\%, Aspek efikasi diri dalam mengingat pengetahuan fisika peserta didik saat pretest sebesar $58 \%$ namun saat posttest menjadi $78 \%$, Aspek efikasi diri dalam melakukan percobaan fisika peserta didik saat pretest sebesar 64\% namun saat posttest menjadi 82\%. Efikasi diri menjadi keyakinan bagi peserta didik tehadap kemampuan, keberhasilan, dan kegigihan mereka didalam belajar serta menyelesaikan tugas matematika [24]. Hal ini sesuai dengan penelitian yang dilakukan oleh Agus yang menyatakan bahwa terdapat hubungan yang positif antara efikasi diri dan kemampuan berpikir kritis [25]-[29]. 


\section{$100 \%$}

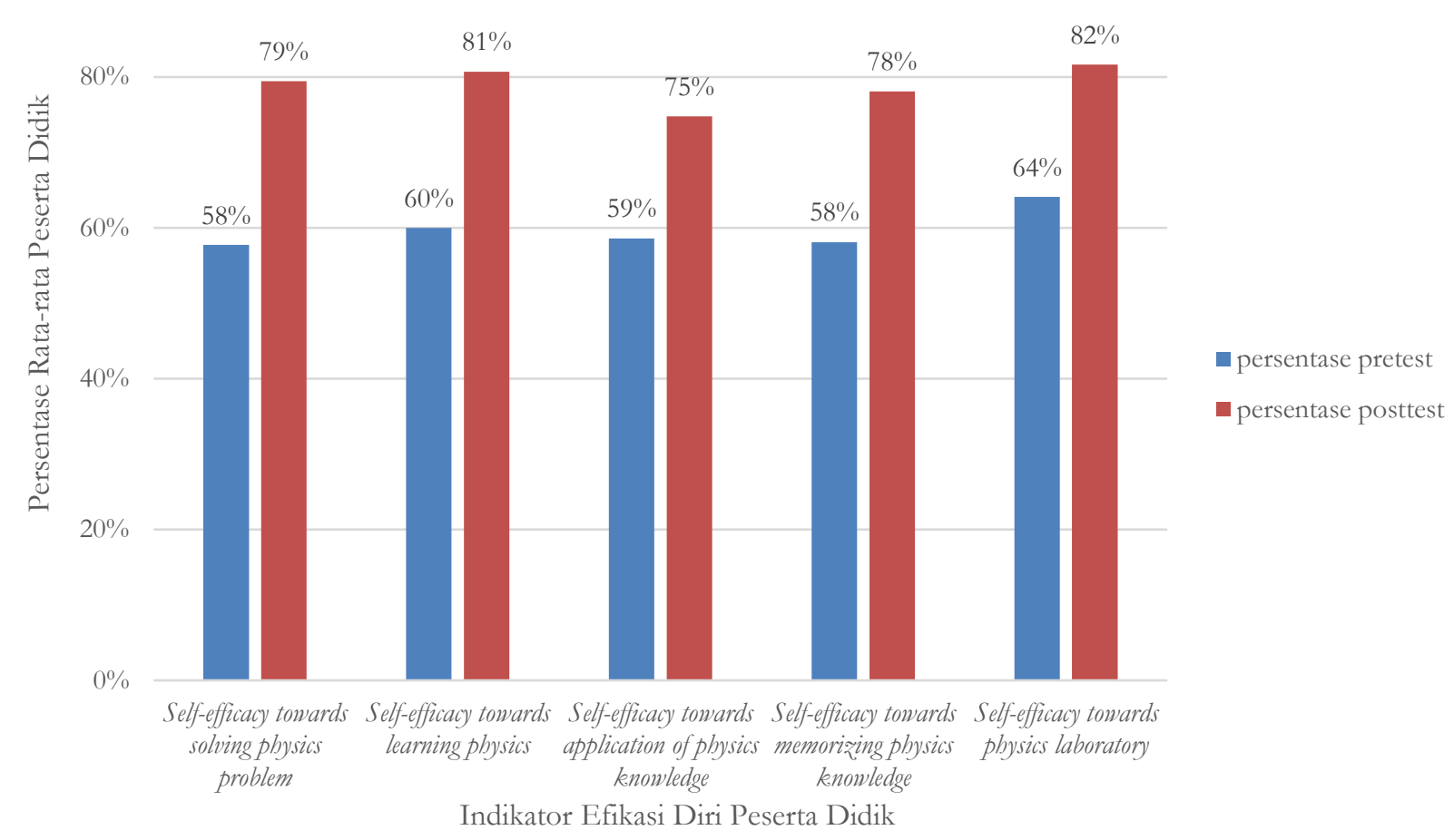

Gambar 1. Persentase rata-rata efikasi diri peserta didik

Sebaliknya, mengacu pada Tabel 3 kisi-kisi soal essay, maka data untuk kemampuan berpikir kritis diperoleh dari perhitungan menggunakan paired samples test berbantuan SPSS versi 23. Hasil kemampuan berpikir kritis dapat dilihat pada Tabel 4 yang ditampilkan di bawah ini.

Tabel 4. Hasil uji paired sample t-test

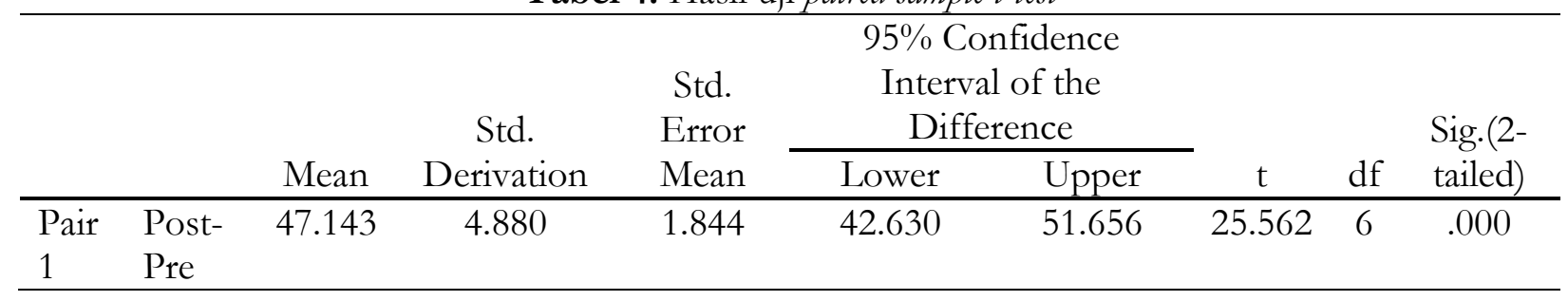

Berdasarkan hasil dari paired sample test, diketahui bahwa t-tabel $(\alpha=0,05, \mathrm{df}=6)=2.446912$ dan t-hitung $=25.562$. Maka, dengan mengikuti syarat: Jika nilai t-hitung $>$ t-tabel, maka H0 ditolak dan Ha diterima, atau Jika nilai t-hitung $<$ t-tabel, maka $\mathrm{H} 0$ diterima dan Ha ditolak. Dimana, H0 = Tidak ada pengaruh penggunaan model PjBL terhadap keterampilan berpikir kritis peserta didik, dan $\mathrm{Ha}=$ Terdapat pengaruh penggunaan model $\mathrm{PjBL}$ terhadap keterampilan berpikir kritis peserta didik. Jika mengacu pada data yang diketahui tersebut, maka t-hitung $>$ t-tabel yaitu $25.562>2.446$ maka $\mathrm{H} 0$ ditolak dan $\mathrm{Ha}$ diterima. Artinya terdapat pengaruh penggunaan model PjBL terhadap keterampilan berpikir kritis peserta didik. Penerapan model pembelajaran PjBL dapat meningkatkan kemampuan berpikir kritis dan hasil belajar peserta didik [30]. Dengan menggunakan pembelajaran PjBL dapat meningkatkan keterampilan berpikir kritis peserta didik [31], [32].

Setelah mengetahui bahwa penggunaan model PjBL memberi pengaruh terhadap kemampuan berpikir kritis peserta didik, sehingga besarnya peningkatan pengaruh tersebut dapat dihitung dengan menggunakan rumus N-Gain. Hasil perhitungan dari rumus N-Gain diperoleh sebesar 0.68. Maka diperoleh hasil bahwa 0.68 masuk pada kategori sedang. Artinya, pengaruh penggunaan model $\mathrm{PjBl}$ terhadap kemampuan berpikir kritis memiliki peningkatan yang cukup signifikan. 
Berdasarkan hasil penelitian yang telah dipaparkan sebelumnya, dapat diartikan bahwa terdapat korelasi positif dan signifikan antara penggunaan model Project Based Learning (PjBL) terhadap efikasi diri maupun kemampuan berpikir kritis peserta didik. Artinya, model PjBL dalam pembelajaran fisika tersebut menjadi salah satu treatment yang dapat mempengaruhi pengembangan kemampuan berpikir kritis peserta didik selain dari aspek efikasi diri yang menjadi fokus utama dalam penelitian ini. Oleh sebab itu, pendidik sebagai fasilitator di kelas perlu menggunakan model $\mathrm{PjBL}$ dalam kegiatan pembelajaran fisika.

$\mathrm{PjBL}$ menjadi salah satu model pembelajaran aktif yang dianggap sesuai dengan kurikulum KKNI. Model PjBL merupakan suatu model yang dalam proses pembelajarannya menuntut peserta didik untuk membuat proyek tertentu [33]. Model PjBL merupakan pembelajaran inovatif yang berpusat pada peserta didik (student centered) dan menempatkan guru sebagai motivator dan fasilitator, dimana peserta didik diberi peluang [34]. Artinya, model PjBL selalu menempatkan peserta didik sebagai peran utama dalam kegiatan pembelajaran dan memungkinkannya memperoleh pengalaman yang bermakna. Pembelajaran proyek adalah proses pembelajaran yang berorientasi pada siswa untuk mendorong eksplorasi aktif [35]. Kegiatan eksplorasi aktif tentunya dapat dilakukan melalui tahapan kegiatan pembelajaran project.

Pembelajaran project terdiri atas beberapa tahapan kegiatan diantaranya diagnosing, prescription, implementing, dan evaluate [36]. Tahap awal yang dilakukan adalah melakukan diagnose yaitu mencari permasalahan/menenmukan isu yang tengah berkembang. Selanjutnya tahap prescription yaitu melakukan perencanaan berdasarkan isu/permasalahan yang telah diperoleh. Kemudian tahap implementing yaitu menerapkan kegiatan/proyek sesuai dengan yang telah direncanakan sebelumnya. Tahap terakhir berupa evaluate yaitu melakukan evaluasi terhadap proyek yang telah dilakukan, apakah permasalahan tersebut terselesaikan atau tidak. Jika tidak, maka dapat mengulang kembali pada tahap awal. Tahapan-tahapan tersebut dilakukan dengan tujuan agar peserta didik memperoleh pengalaman belajar.

Perolehan konsep dan pengalaman belajar peserta didik dibangun berdasarkan produk yang dihasilkan dalam proses pembelajaran berbasis proyek [37]. Jika merujuk pada segi pelaksanaan pembelajarannya maka kegiatan belajar berbasis proyek dilakukan secara sistematis. Artinya, kegiatan belajar dengan melibatkan peserta didik melalui proyek berupa tugas penelitian yang menantang, soalsoal/pertanyaan otentik serta produk yang dirancang dengan baik dalam hal memperoleh pengetahuan dan keterampilan. Dalam pembelajaran PjBL peserta didik dapat memainkan peran sentral dalam merancang, memecahkan masalah dan membuat keputusan yang memungkinkan siswa untuk bekerja secara mandiri [38]. Selain itu, model PjBL tersebut cocok digunakan dalam pembelajaran IPA karena mampu meningkatkan self efficacy siswa yaitu teguh keyakinan dan diri sendiri dalam melakukan tugas [39]. Melalui PjBL peserta didik secara tidak langsung dan bertahap dapat mengembangkan efikasi diri yang ada dalam dirinya.

Efikasi diri (self efficacy) adalah kepercayaan diri yang ada dalam diri peserta didik terhadap kemampuannya dalam memecahkan masalah. Efikasi diri merupakan bagian dari kepribadian yang memungkinkan peserta didik yakin untuk dapat melakukan suatu tindakan yang mempengaruhi hidupnya. Salah satu faktor kepribadian yang berperan penting adalah efikasi diri [40]. Efikasi diri merupakan variabel penting yang harus dimiliki oleh peserta didik, sebab mereka yang memiliki efikasi diri cenderung menggunakan strategi belajar kognitif [41]. Artinya, efikasi diri mempengaruhi peserta didik dalam memotivasi diri, berpikir dan membuat keputusan, khususnya yang berkaitan dengan masalah dalam lingkup fisika.

Efikasi diri dan kemampuan berpikir kritis dalam pembelajaran fisika saling berhubungan positif [42], [43]. Efikasi diri pada dasarnya menjadi faktor yang dapat menumbuhkembangkan kemampuan berpikir kritis peserta didik dalam menyelesaikan tugas/proyek. Dalam hal ini, isu/permasalahan yang ditemukan untuk membuat proyek dapat dibuat oleh pendidik dalam bentuk pertanyaan melalui tahap PjBL. Pertanyaan tersebut nanti difokuskan pada materi yang akan diajarkan dan berkaitan dengan proyek yang akan dibuat. Peserta didik yang mendapat pertanyaan-pertanyan bersifat kritis secara tidak langsung dapat mengembangkan kemampuan berpikir kritisnya dalam mempelajari materi secara mendalam dan mandiri. Pertanyaan yang diajukan dapat diberikan di awal pertemuan agar peserta didik lebih terarah dalam melakukan pengerjaan proyek dan eksperimen. 
Keterampilan berpikir kritis merupakan potensi atau cara berpikir yang memberikan pertanyaan, percobaan, dan keyakinan terhadap pengetahuan yang diperoleh melalui percobaan yang dapat diukur, dilatih dan dikembangkan [44], [45]. Mengingat bahwa pada dasarnya kemampuan berpikir kritis merupakan salah satu perwujudan dari HOTS [46], [47]. Berpikir kritis sebagai sebuah proses berpikir yang berhubungan dengan kemampuan dalam menganalisis dan mengevaluasi [48]. Tahap pada kemampuan menganalisis dan mengevaluasi dilakukan untuk memperoleh hasil terbaik. Berpikir kritis melibatkan taksonomi bloom yang meliputi kemampuan analisis, evaluasi dan berpendapat lebih lanjut [49]. Berpikir kritis merupakan kemampuan berpikir tingkat tinggi meliputi kemampuan C4, C5 dan C6 dari taksonomi Bloom.

Kemampuan berpikir kritis menjadikan peserta didik lebih mampu dalam membuat simpulan secara logis dan mengevaluasi simpulan yang telah disusun. Berpikir kritis merupakan penggerak bagi diri sendiri karena proses berpikir yang dimiliki dapat dikendalikan melalui pertanyaan dan perlakuan tes. Karakteristik peserta didik yang memiliki kemampuan berpikir kritis dapat dilihat melalui rasa ingin tahu terhadap tingkat permasalahan yang dihadapi, keinginan untuk menjadi pribadi yang lebih baik, jujur dalam hal penemuan suatu hal fleksibel dalam hal penyelesaian dan lainnya [50]. Pemecahan tugas proyek yang kompleks melibatkan pengetahuan tingkat tinggi dengan pendekatan kelompok/koperatif sebagai cara menemukan solusi yang tepat [51].

Penerapan Project Based Learning (PjBL) dalam pembelajaran fisika membuat peserta didik memiliki proses pembelajaran yang bermakna. Pembelajaran yang dikembangkan berdasarkan faham konstruktivisme, dengan memberi kesempatan untuk menggali sendiri informasi melalui membaca berbagai buku secara langsung, bekerja dalam kelompok, membuat presentasi dan mengkomunikasikan hasil aktivitasnya kepada orang lain. Semuanya menggambarkan tentang bagaimana semestinya orang dewasa belajar agar lebih bermakna. Sehingga memungkinkan bagi peserta didik untuk dapat mengembangkan efikasi diri dan meningkatkan kemampuan berpikir kritisnya.

\section{KESIMPULAN}

Pembelajaran fisika menggunakan model Project Based Learning (PjBL) berpengaruh positif terhadap efikasi diri dan dapat meningkatkan kemampuan berpikir kritis peserta didik dengan peningkatan yang cukup signifikan. Project Based Learning (PjBL) selian dapat meningkatkan efikasi diri peserta didik, juga dapat meningkatkan kemampuan peserta didik dalam berpikir kritis dimana kemampuan berpikir kirits merupakan salah satu ciri kemampuan berpikir tingkat tinggi.

\section{DAFTAR PUSTAKA}

[1] H. Permana, F. Harahap, and B. Astuti, "Hubungan Antara Efikasi Diri Dengan Kecemasan Dalam Menghadapi Ujian Pada Siswa Kelas IX Di MTs Al Hikmah Brebes," Hisbah J. Bimbing. Konseling dan Dakwah Islam, vol. 13, no. 2, pp. 51-68, Mar. 2017, doi: 10.14421/hisbah.2016.13204.

[2] J. M. Ivancevich, J. L. Gibson, and R. Konopaske, Organizations: Behavior, Structure, Processes. McGraw-Hill Education, 2011.

[3] D. B. McCoach, R. K. Gable, and J. P. Madura, Instrument Development in the Affective Domain. New York, NY: Springer New York, 2013.

[4] R. A. Simon, M. W. Aulls, H. Dedic, K. Hubbard, and N. C. Hall, "Exploring Student Persistence in STEM Programs: A Motivational Model," Can. J. Educ. / Rev. Can. l'éducation, vol. 38, no. 1, pp. 1-27, Apr. 2015.

[5] M. Dehghani, H. J. Sani, H. Pakmehr, and A. Malekzadeh, "Relationship between Students' Critical Thinking and Self-efficacy Beliefs in Ferdowsi University of Mashhad, Iran," Procedia Soc. Behav. Sci., vol. 15, pp. 2952-2955, 2011, doi: 10.1016/j.sbspro.2011.04.221.

[6] Y.-S. Lee and Y. Eun, "The Effect of the Flipped Learning on Self-efficacy, Critical Thinking Disposition, and Communication Competence of Nursing Students," J. Korean Acad. Soc. Nurs. Educ., vol. 22, no. 4, pp. 567-576, Nov. 2016, doi: 10.5977/jkasne.2016.22.4.567.

[7] D. Rusmansyah, L. Yuanita, M. Ibrahim, and D. Isnawati, "Improving Critical Thinking Skills 
and Self Efficacy Through Scientific Critical Thinking Model," in Proceedings of the 1 st International Conference on Creativity, Innovation and Technology in Education (IC-CITE 2018), 2018, doi: 10.2991/iccite-18.2018.57.

[8] O. R. Riyanto, S. B. Waluya, and S. Mariani, "Mathematics Critical Thinking Reviewed from Self-efficacy and Motivation of Learning in Arias Learning," J. Prim. Educ., vol. 8, no. 5, pp. 243-250, 2019.

[9] A. Eghtesadi and A. Jeddi, "Teachers' Critical Thinking and Self-efficacy as Predictors of their Pedagogical Success," Int. J. Appl. Linguist. English Lit., vol. 8, no. 1, pp. 62-70, 2019.

[10] W. Hughes, J. Lavery, and K. Doran, Critical Thinking: An Introduction to the Basic Skills - Seventh Edition. Broadview Press, 2014.

[11] M. Firdaus and I. Wilujeng, "Pengembangan LKPD inkuiri terbimbing untuk meningkatkan keterampilan berpikir kritis dan hasil belajar peserta didik," J. Inov. Pendidik. IP A, vol. 4, no. 1, pp. 26-40, 2018, doi: 10.21831/jipi.v4i1.5574.

[12] A. Chase, D. Pakhira, and M. Stains, "Implementing Process-Oriented, Guided-Inquiry Learning for the First Time: Adaptations and Short-Term Impacts on Students' Attitude and Performance," J. Chem. Educ., vol. 90, no. 4, pp. 409-416, Apr. 2013, doi: 10.1021/ed300181t.

[13] Husamah, Pembelajaran Luar Kelas Outdoor Activity. Jakarta: Prestasi Pustaka, 2013.

[14] C. J. Marsh, Becoming a Teacher: Knowledge, Skills and Issues. Pearson Australia, 2010.

[15] W. N. Bender, Project-Based Learning Differentiating Instruction for the 21 Century. Thousand Oaks: Corwin, 2012.

[16] G. D. Borich, Effective Teaching Methods. Indianapolis: Merrill Publishing Company, 1995.

[17] S. Cąliş̧kan, G. S. Selçuk, and M. Erol, "Development of Physics Self-Efficacy Scale," in AIP Conference Proceedings, 2007, vol. 899, pp. 483-484, doi: 10.1063/1.2733247.

[18] S. Çaliş̧kan, G. S. Selçuk, and M. Erol, "Development of Physics Self-Efficacy Scale," in AIP Conference Proceedings, 2007, vol. 899, pp. 483-484, doi: 10.1063/1.2733247.

[19] K. K. Cheng, B. A. Thacker, R. L. Cardenas, and C. Crouch, "Using an online homework system enhances students' learning of physics concepts in an introductory physics course," Am. J. Phys., vol. 72, no. 11, pp. 1447-1453, Nov. 2004, doi: 10.1119/1.1768555.

[20] M. Erfan, M. A. Maulyda, G. Gunawan, N. Sari, and T. Ratu, "Enhancing Students Ability in Analyzing Image Formation on Lens and Mirror Using Ray Optics," J. Phys. Conf. Ser., vol. 1471, p. 012061, Feb. 2020, doi: 10.1088/1742-6596/1471/1/012061.

[21] M. Erfan, M. A. Maulyda, V. R. Hidayati, A. Widodo, and T. Ratu, "Utilization of the Android physics virtual lab application to improve understanding of light and optics concepts," IOP Conf. Ser. Mater. Sci. Eng., vol. 1088, no. 1, p. 012016, Feb. 2021, doi: 10.1088/1757899X/1088/1/012016.

[22] R. R. Hake, "Interactive-engagement versus traditional methods: A six-thousand-student survey of mechanics test data for introductory physics courses," Am. J. Phys., vol. 66, no. 1, pp. 64-74, Jan. 1998, doi: 10.1119/1.18809.

[23] L. W. Anderson and D. R. Krathwohl, A Taxonomy for Learning, Teaching, and Assessing: A Revision of Bloom's Taxonomy of Educational Objectives. 2001.

[24] X. Liu and H. Koirala, "The Effect of Mathematics Self-Efficacy on Mathematics Achievement of High School Students," NERA Conf. Proc. 2009, 2009.

[25] I. Agus, "Hubungan Antara Efikasi Diri dan Kemampuan Berpikir Kritis Matematika Siswa," Delta J. Ilm. Pendidik. Mat., vol. 9, no. 1, p. 1, Jan. 2021, doi: 10.31941/delta.v9i1.1061.

[26] M. Gazali, "Pengaruh Efikasi Diri dan Kecemasan Matematika terhadap Kemampuan Berpikir Kritis," J. Penelit. dan Penilai. Pendidik., vol. 2, no. 2, pp. 274-289, 2017.

[27] H. P. Phan, "Relations between goals, self-efficacy, critical thinking and deep processing strategies: a path analysis," Educ. Psychol., vol. 29, no. 7, pp. 777-799, Dec. 2009, doi: 10.1080/01443410903289423.

[28] Y. Sukma and N. Priatna, "Pengaruh Self-Efficacy terhadap Kemampuan Berpikir Kritis Siswa Pada Mata Pelajaran Matematika," J. Ilm. Soulmath J. Edukasi Pendidik. Mat., vol. 9, no. 1, p. 75, Mar. 2021, doi: 10.25139/smj.v9i1.3461.

[29] M. D. Basito, R. Arthur, and D. Daryati, "Hubungan Efikasi Diri Terhadap Kemampuan 
Berpikir Tingkat Tinggi Siswa SMK Program Keahlian Teknik Bangunan Pada Mata Pelajaran Mekanika Teknik," J. PenSil, vol. 7, no. 1, pp. 21-34, Feb. 2018, doi: 10.21009/pensil.7.1.3.

[30] A. A. Priyambodo, S. H. Nurdiniah, and Rusmansyah, "Meningkatkan Kemampuan Berpikir Kritis dan Hasil Belajar Materi Sistem Koloid melalui Model Project Based Learning (PjBL) pada Siswa Kelas XI IPA SMA Negeri 7 Banjarmasin Tahun Pelajaran 2013/2014,” Tidak dipublikasikan, pp. 1-18, 2014.

[31] J. Afriana, A. Permanasari, and A. Fitriani, "Penerapan project based learning terintegrasi STEM untuk meningkatkan literasi sains siswa ditinjau dari gender," J. Inov. Pendidik. IP A, vol. 2, no. 2, p. 202, Oct. 2016, doi: 10.21831/jipi.v2i2.8561.

[32] N. Luthvitasari, N. M. D. P, and S. Linuwih, "Implementasi Pembelajaran Fisika Berbasis Proyek Terhadap Keterampilan Berpikir Kritis, Berpikir Kreatif Dan Kemahiran Generik Sains," J. Innov. Sci. Educ., vol. 1, no. 2, pp. 92-97, 2012.

[33] D. Desyandri and P. Maulani, "Penerapan Model Project Based Learning untuk Meningkatkan Hasil Belajar Seni Musik Pada Pembelajaran Tematik Terpadu di Sekolah Dasar," J. Inov. Pendidik. DAN PEMBELAJARAN Sekol. DASAR, vol. 3, no. 2, p. 58, Jan. 2020, doi: 10.24036/jippsd.v3i2.107576.

[34] N. M. Y. Suranti, G. Gunawan, and H. Sahidu, "Pengaruh Model Project Based Learning Berbantuan Media Virtual Terhadap Penguasaan Konsep Peserta didik pada Materi Alat-alat Optik," J. Pendidik. Fis. dan Teknol., vol. 2, no. 2, p. 73, Apr. 2017, doi: 10.29303/jpft.v2i2.292.

[35] S. Nagarajan and T. Overton, "Promoting Systems Thinking Using Project- and ProblemBased Learning," J. Chem. Educ., vol. 96, no. 12, pp. 2901-2909, Dec. 2019, doi: 10.1021/acs.jchemed.9b00358.

[36] R. Stoecker, Research Methods for Community Change A Project-Based Approach. SAGE Publications, Inc, 2005.

[37] R. M. Capraro, M. M. Capraro, and J. Morgan, STEM Project-Based Learning: An Integrated Science, Technology, Engineering, and Mathematics (STEM) Approach. Rotterdam: SensePublishers, 2013.

[38] W. Sumarni, "The Strengths and Weaknesses of the Implementation of Project Based Learning: A Review," 2015.

[39] N. W. Y. Amanda, I. W. Subagia, and I. N. Tika, "Pengaruh Model Pembelajaran Berbasis Proyek Terhadap Hasil Belajar IPA Ditinjau Dari Self Efficacy Siswa," J. Pendidik. dan Pembelajaran IP A Indones., vol. 4, no. 1, pp. 1-11, 2014.

[40] L. Hoffman, C. Hutchinson, and E. Reiss, "On improving school climate: Reducing reliance on rewards and punishment," 2009.

[41] R. E. Slavin, Educational Psychology: Theory and Practice. Pearson, 2012.

[42] P. D. Sundari, P. Parno, and S. Kusairi, "Hubungan antara efikasi-diri dan kemampuan berpikir kritis siswa," in Seminar Nasional Pendidikan IP A Pascasarjana UM, 2016.

[43] S. Nurazizah and A. Nurjaman, "Analisis Hubungan Self Efficacy Terhadap Kemampuan Berpikir Kritis Matematis Siswa Pada Materi Lingkaran," JPMI (Jurnal Pembelajaran Mat. Inov., vol. 1, no. 3, p. 361, May 2018, doi: 10.22460/jpmi.v1i3.p361-370.

[44] S. Susilowati and M. Ramli, "Analisis Keterampilan Berpikir Kritis Siswa Madrasah Aliyah Negeri di Kabupaten Magetan," in Seminar Nasional Pendidikan Sains, 2017, pp. 223-231.

[45] Lambertus, "Pentingnya Melatih Keterampilan Berpikir Kritis dalam Pembelajaran Matematika di SD," Forum Kependidikan, vol. 28, no. 2, pp. 136-142, 2009.

[46] M. Erfan and T. Ratu, "Pencapaian HOTS (Higher Order Thinking Skills) Mahasiswa Program Studi Pendidikan Fisika FKIP Universitas Samawa," J. Pendidik. Fis. dan Teknol., vol. 4, no. 2, p. 208, Nov. 2018, doi: 10.29303/jpft.v4i2.831.

[47] D. S. Sari and K. H. Sugiyarto, "Pengembangan Multimedia Berbasis Masalah Untuk Meningkatkan Motivasi Belajar Dan Kemampuan Berpikir Kritis Siswa," J. Inov. Pendidik. IPA, vol. 1, no. 2, p. 153, Oct. 2015, doi: 10.21831/jipi.v1i2.7501.

[48] R. Paul and L. Elder, "Critical \& Thinking Guide," Fond. Crit. Think. Press, vol. 5, pp. 565-617, 2008.

[49] J. Butterworth and G. Thwaites, Thinking Skills Critical Thinking and Problem Solving. Cambridge International AS, 2016. 
[50] G. Crebert, C.-J. Patrick, V. Cragnolini, C. Smith, K. Worsfold, and F. Webb, Problem Solving Skills Toolkit 2nd Edition. Queensland: Griffith University, 2011.

[51] M. Mureşan, "Project Based Collaborative Learning For Adult Education," eLearning Softw. Educ., vol. 7, no. 3, pp. 303-309, 2014. 